\title{
Exploration of Flesh Dammar (Shorea Leprosula Miq) and Cat Eye Dammar (Shorea Javanica K.Et.V.) As Antibacterial Agent
}

\author{
${ }^{1,}$ Noryawati Mulyono, ${ }^{2}$ Bibiana Widiyati Lay, ${ }^{3,}$ Mukti Wahyuningjati ${ }^{1}$ \\ ${ }^{1,2,3}$ School of Biology, Faculty Biotechnology, Atma Jaya Catholic University
}

\begin{abstract}
Dammar resins are nontimber tropical forest products from Dipterocarpaceae plants. The resins are produced as secondary metabolites induced by malnutrition and drought. The objective of this research was to evaluate the antibacterial activity of flesh dammar and cat eye dammar. The resins were separately extracted using three solvents, i.e. hexane, ethyl acetate, and ethanol for $24 \mathrm{~h}$ at $50 \mathrm{~g} \mathrm{~L}^{-1}$. Antibacterial activity assay was performed against Escherichia coli, Salmonella typhi, Proteus mirabilis, Pseudomonas aeruginosa, Chromobacter violaceum, Streptococcus sp., Staphylococcus aureus, S. epidermidis, and Bacillus cereus. The result showed that flesh dammar had antibacterial activity but cat eye dammar did not have. According to the antibacterial activity and the yield, the best solvent for extracting flesh dammar was ethyl acetate. The obtained extract could inhibit C. violaceum, Streptococcus sp., S. aureus, S. epidermidis, and B. cereus. Their MICs were $32 \mathrm{ppm}$ for C. violaceum and 256 ppm for other bacteria tested. None of cat eye dammar extracts had antibacterial activity.
\end{abstract}

Keywords - Antibacterial Activity, Cat Eye Dammar, C. Violaceum, Flesh Dammar, Gram-Positive.

\section{INTRODUCTION}

Dammar resins are nontimber products from tropical forest plants, belonging to Dipterocarpaceae family. Indonesia has many species of dammar. Dammar grows well in virgin forests as well as in agro-forests in Sumatera, Java, Kalimantan, Sulawesi, Maluku, and West Papua. Traditionally, flesh dammar (Shorea leprosula) has been used to heal leprosy. Cat eye dammar (S. javanica) had antifungal and anti-termite activities [1], however the activities of dammar against food-borne bacteria has not been reported yet. Due to many foodborne outbreaks and microbe resistance to synthetic antimicrobials, natural antimicrobial is urgently needed. Approximately, 10000-20000 people per 1000000 of the population in developed countries suffer from foodborne disease every year [2]. This research was carried out to evaluate the antibacterial activity of flesh dammar and cat eye dammar.

\subsection{Material}

\section{MATERIALS AND METHODS}

All reagents were analytical grade (Merck). Flesh dammar and cat eye dammar were bought from dammar trader in Sumatera in 2009. The former looked like irregular stone and its inside looked as beef meat, waxy and tough. The latter is fragile, pale yellow, and could be milled.The reference bacteria for antibacterial activity were Escherichia coli, Salmonella typhi, Pseudomonas aeruginosa, Proteus mirabilis, Chromobacter violaceum, Streptococcus sp., Staphylococcus aureus, S. epidermidis, and Bacillus cereus. They were provided by the culture collection of Laboratory of Microbiology and Fermentation, Atma Jaya Catholic University. Bacteria to be used for antibacterial activity assay were standardized in sterile saline solution following 0.5 MacFarland scale [3]. Nutrient Agar (Oxoid) was used for culture medium. Mueller Hinton Agar (MHA) was used as media to determine antibacterial activity. All experiments were done triplicate.

\subsection{Dammar extraction}

Both small pieces of flesh dammar and milled flour of cat eye dammar were extracted at room temperature using analytical grade of hexane, ethyl acetate, and ethanol separately at $50 \mathrm{~g} \mathrm{~L}^{-1}$. Each of them was filtrated, subsequently soluble fractions were concentrated by vacuum rotary evaporator until the final volume became $10 \%$ of initial filtrate.

\subsection{Antibacterial activity assay}

The assay was performed by determining the inhibition zone using agar well diffusion, minimum inhibition concentration (MIC), and minimum bactericidal concentration (MBC). As much as $15 \mu \mathrm{L}$ extract, negative controls (solvents for extracting dammar), and positive control (tetracycline $50 \mu \mathrm{g} \mathrm{mL}^{-1}$ ) were filled in each of the $4 \mathrm{~mm}$-diameter well and incubated at $37^{\circ} \mathrm{C}$ for $24 \mathrm{~h}$. The clear zone around the well indicated that 
the growth of bacteria was inhibited by the sample. Further antibacterial test was done by determining the MIC and MBC. The MIC was defined as the lowest concentration of antimicrobials at which there is no visible growth [3]. Dammar extract was suspended in Tween $201 \mathrm{~mL} \mathrm{~L}^{-1}$ at two-fold serial dilution from 0.5 to 512 ppm, subsequently $400 \mu \mathrm{L}$ bacterial suspension and $3600 \mu \mathrm{L}$ Nutrient Broth (NB, Oxoid) were added to each of them. The mixture of $400 \mu \mathrm{L}$ bacterial suspension and $3600 \mu \mathrm{L}$ NB was used as negative control. The positive control was the mixture of $10 \mu \mathrm{L}$ tetracycline $50 \mu \mathrm{g} \mathrm{mL} \mathrm{L}^{-1}, 400 \mu \mathrm{L}$ bacterial suspension, and $3590 \mu \mathrm{L}$ NB. The MBC was defined as the lowest concentration of antimicrobials at which there is no visible growth of bacteria on agar media. It was determined by sub-culturing $10 \mu \mathrm{L}$ of three consecutive positive results of MIC test onto MHA for $24 \mathrm{~h}$ at $37^{\circ} \mathrm{C}[4]$.

\section{RESULTS AND DISCUSSION}

The extraction of flesh dammar using ethyl acetate produced the highest soluble matter and the broadest antibacterial activity spectrum compared to other solvents. The inhibition zone of ethyl acetate extract was also the largest compared to other extracts of flesh dammar (TABLE 1). Obviously, ethyl acetate was the best solvent for obtaining antibacterial agent from flesh dammar compared to hexane and ethanol.

Table 1. Soluble matter and antibacterial activity of flesh dammar extract

\begin{tabular}{lllllll}
\hline Solvent & $\begin{array}{l}\text { Soluble } \\
\text { matter } \\
(\% \mathrm{w} / \mathrm{w})\end{array}$ & C.violaceum & $\begin{array}{l}\text { Streptococcus } \\
\text { sp. }\end{array}$ & S. aureus & S. epidermidis & B. cereus \\
\hline Hexane & 38.24 & - & - & - & - & $6.0 \pm 0$ \\
Ethyl acetate & 58.79 & $17.0 \pm 0.5$ & $7.0 \pm 0$ & $7.0 \pm 0$ & $6.3 \pm 0.3$ & $7.7 \pm 0.3$ \\
Ethanol & 52.17 & - & - & - & - & - \\
\hline
\end{tabular}

TABLE 1 indicated that this extract could inhibit all Gram-positive bacteria tested, i.e: Streptococcus sp., S. aureus, S. epidermidis, and B. cereus. Those bacteria had one layer cell wall and its major component was peptidoglycan which was easily to be penetrated with antibacterial agent [5]. Other bacteria, such as E. coli, S. typhi, P. aeruginosa, and P. mirabilis could not be inhibited by the extract. These Gram-negative bacteria had a multilayer cell wall and its outer membrane contained lipopolysaccharide. This complex macromolecule had polar glycoside group on the surface which hindered lipophillic compounds to enter the cell. The exceptional data was shown by $\mathrm{C}$. violaceum, which was inhibited by the extract. In addition, its inhibition zone was larger than that of the Gram-positive bacteria tested. This activity probably was caused by the interaction between the extract and the unique metabolite from $\mathrm{C}$. violaceum, namely violacein pigment. The other possibility was that these bacteria possessed similar mesosome to Gram-positive bacteria [6]. The activity of ethyl acetate extract was less than that of tetracycline. This synthetic antibiotic could inhibit the growth of all tested bacteria and the inhibition zone range was higher than the flesh dammar extract (TABLE 2). The antibacterial activity of ethyl acetate extract would be probably improved if the extract is to be purified.

Table 2. Inhibition zone of tetracycline against bacteria tested

\begin{tabular}{lc|lc}
\hline & Gram-negative bacteria & \multicolumn{2}{c}{ Gram-positive bacteria } \\
Species & Inhibition zone $(\mathrm{mm})$ & Species & Inhibition zone $(\mathrm{mm})$ \\
\hline C. violaceum & $22.5 \pm 1.0$ & Streptococcus sp. & $18.5 \pm 1.0$ \\
E. coli & $14 \pm 0.3$ & S. aureus & $16.7 \pm 0.3$ \\
S. typhi & $18 \pm 1.0$ & S. epidermidis & $14.8 \pm 0.3$ \\
P. mirabilis & $7 \pm 0.3$ & B. cereus & $18.3 \pm 0.3$ \\
P. aeruginosa & $8 \pm 0.3$ & & \\
\hline \hline
\end{tabular}

The MIC of C. violaceum was 32 ppm, while the other Gram-positive bacteria tested showed similar results $(256 \mathrm{ppm})$. From agar well diffusion and MIC test, C. violaceum was the most sensitive bacteria to ethyl acetate extract. The activity of ethyl acetate extracts against Gram-positive bacteria was similar. The MBC test indicated that the extract could not kill the bacteria.Mulyono [7] reported that hexane and ethyl acetate extract from flesh dammar contained trans-caryophyllene, veridiflorol, $\alpha$-copaene, $\delta$-cadinene, $\beta$-elemene, aromadendrene, (-)-isoledene, and 1S,cis-calamenene. Those compounds were also present in Ottonia martiana which had similar antibacterial activity spectrum. Essential oil of leaves, fruits, and roots of O. martiana could inhibit the growth of S. aureus and S. epidermidis, but did not inhibit P. aeruginosa and E. coli [8]. In comparison, Vukovic et al. [9] reported that trans-caryophyllene was present in essential oil from Teucrium montanum which effectively inhibited the growth of some Gram-negative bacteria (Agrobacterium tumefaciens, Azotobacter chlorococcum, Enterobacter cloaceae, Erwinia carotovora, Klebsiella pneumonia, P. glycinea, P. 
fluorescens, and P. phaseolicola), Gram-positive bacteria (B. mycoides, B. subtilis, S. aureus), and fungi (Aspergillus niger, Fusarium oxysporum, and Penicillium canescens). Other compounds such as driminol, juniper camphor, cycloisolongifolene, and $\beta$-guaiene were also present in hexane and ethyl acetate extracts from flesh dammar but their activities have not been reported yet. In ethyl acetate extract, there were some other compounds which might have antibacterial activities, such as $\gamma$-gurjunene, palustrol, aristolene, $\alpha$-guaiene, $\alpha$ cadinol, $\alpha$-amorphene, valencene, and naphthalene derivatives. None of the cat eye dammar extract had antibacterial activity even though this dammar had anti-termite and antifungal activities [1]. Mulyono et al. [10] reported that the major component of that dammar was brassicasterol (approximately 20\%), which is well known as anticholesterol agent [11].

\section{IV.CONCLUSION}

Finally, it can be concluded that flesh dammar could be developed as natural antibacterial agent and the best solvent to obtain the active compounds was ethyl acetate. For further research, its activity against other harmful bacteria, its mechanism of inhibition, and application in pharmaceutical, food, and packaging should be investigated.

\section{Acknowledgements}

We would like to thank School of Biotechnology, Atma Jaya Catholic University for providing us the financial support for this study.

\section{REFERENCES}

[1]. R.K. Sari, Isolasi dan identifikasi komponen bioaktif dari damar mata kucing (Shorea javanica K.et.V). doctoral diss., Institut Pertanian Bogor, Bogor, 2002.

[2]. S. Notermans, H. Hofstra, and G. Wirtanen, Newly food-borne emerging pathogens, including risk assessment and risk management. Proc. FOSARE Seminar Series 1, Brussels, 2003.

[3]. [CLSI] Clinical Laboratory Standards Institute, Methods for dilution antimicrobial susceptibility tests for bacteria that grow aerobically; approved standard, $8^{\text {th }}$ ed, 2009. http://www.clsi.org/source/orders/free/m07-a8.pdf, Accessed on 05-06-11.

[4]. R.V. Goering, H. Dockrell, M. Zuckerman, D. Wakelin, I. Roitt, C. Mims, and P. Chiodini, Medical microbiology (London: Mosby Ltd, 2007).

[5]. A. Nostro, M.P. Germano, V.D. Angelo, A. Marino, and M.A. Cannatelli, Extraction methods and bioautography for evaluation of medicinal plant antimicrobial activity. Letters in Applied Microbiology, 30, 2000, 379-384.

[6]. T.E. Rucinky and E.H. Cota-Robles, Mesosome Structure in Chromobacterium violaceum. Journal of Bacteriology, 118(2), 1974, 717724.

[7]. N. Mulyono, Chemical constituents in flesh dammar extracts and their potencies as antibacterial agent. Proc. 3rd ICMNS, Bandung, Indonesia, 2010, 552-557.

[8]. M.M. Cunico, A.L. Lopes, L.C. Cocco, C.I. Yamamoto, R.C.B. Plocharski, M.D. Miguel, A.G. Junior, C.G. Auer, and O.G. Miguel, Phytochemical and antibacterial evaluation of essential oils from Ottonia Martiana Miq. (Piperaceae). Journal of the Brazilian Chemical Society, 18(1), 2007, 184-188.

[9]. N. Vukovic, T. Milosevic, S. Sukdolak, and S. Solujic, Antimicrobial activities of essential oil and methanol extract of Teucrium montanum. Evid Based Complement Alternat Med., 4(1), 2007, 17-20.

[10]. N. Mulyono, C.H. Wijaya, D. Fardiaz, and W.S. Rahayu, Identifikasi komponen kimia damar mata kucing (Shorea javanica) dengan metode pirolisis-GC/MS. Jurnal Natur Indonesia, 14(1), 2010, 155-159.

[11]. R. Sahelian, Health benefit of brassicasterol. Free Supplement Res Update Newsletter. 2009. http://www.raysahelian.com Accessed on 05-02-09. 